\title{
Differences in paediatric rheumatology services in European countries - results of an international survey R Vesely
}

\author{
Address: Faculty Children's Hospital, Kosice, Slovakia \\ from I5th Paediatric Rheumatology European Society (PreS) Congress \\ London, UK. 14-17 September 2008 \\ Published: I5 September 2008 \\ Pediatric Rheumatology 2008, 6(SuppI I):PI49 doi:I0.II86/I546-0096-6-SI-PI49
}

This abstract is available from: http://www.ped-rheum.com/content/6/SI/PI49

(C) 2008 Vesely; licensee BioMed Central Ltd.

\section{Background}

Despite current unifying process profound historical variability exists in Europe resulting also in differences in social welfare and quality of health care. To overcome these differences and build equal European standard of care it is necessary to study and understand these differences.

\section{Materials and methods}

During April 2008 international paediatric rheumatology community was invited to complete the survey using http://www.surveymonkey.com web based instrument. The invitation letters were sent by e-mail to all PReS members and PRINTO members from European countries. Survey consisted of 36 questions structured in 6 domains:

About you

About the country you currently work in

About your centre

About your routine

About your research and international co-operation

About your wishes

\section{Results}

133 responses were collected before May 22nd 2008 from 33 countries, among them 12 from 8 non-European countries.

The responses were stratified according the gross income per capita http://web.worldbank.org and 2 groups of countries were created. Comparison of these two groups showed significant differences in the following areas:

Number of paediatric rheumatologists per capita, number of centres, accessibility of treatments, research activities and international co-operation, language skills and relative average income of paediatric rheumatologists.

\section{Conclusion}

The results of this survey can help to define future strategies to improve paediatric rheumatology services in two ways. European standard of care should be developed to stimulate the governments of "underperforming countries" and support programmes should be focused on the areas where main differences were found.

\section{Acknowledgements}

The author wishes to thank all who responded the survey. 